\title{
EFEKTIFITAS KOMUNIKASI PEMBELAJARAN ONLINE DENGAN MENGGUNAKAN MEDIA E-LEARNING PADA PERKULIAHAN BODY OTOMOTIF
}

Basori

\author{
Prodi. Pend. Teknik Mesin, Jurusan Pendidikan Teknik dan Kejuruan, FKIP, UNS \\ Kampus UNS Pabelan Jl. Ahmad Yani 200, Surakarta, Telp/Fax 0271718419 \\ Email:basori@fkip.uns.ac.id
}

\begin{abstract}
This study aims to determine the effectiveness of learning communication with e-learning models on the Body of Automotive lecture. The course material is included in the e-learning website at FKIP UNS.

The methods of this study is a qualitative methods and it is used the Ex Post Facto. The population of the study was all students taking the automotive concentration. Data collection was done through a questionnaire. Data analysis was done by a descriptive.

Based on the study result, we got the conclusion that: (1) the teaching material is quite understandable by students, (2) the material such as text, images, sound, and harmony in all three teaching materials can be received clearly by students, (3) The teaching material increases knowledge of students, (4) e-learning mode directs the student to agree with the teaching material, (5) e-learning mode encourages the students to complete the task of e-learning teaching material. In general, the study found that the delivery of course material's to students through the e-learning model's was effective. so, we could concluded the learning communication is effective.
\end{abstract}

Key words: learning communication, e-learning, Body of Automotive

\section{PENDAHULUAN}

Pendidikan bersifat dinamis di mana selalu ada perubahan-perubahan di setiap saat sehingga menuntut adanya suatu perbaikan yang bersifat kontinu atau terus menerus dalam perkembangan di dunia pendidikan. Peran pendidikan sangat penting terutama untuk menciptakan kehidupan yang cerdas, damai, terbuka dan demokratis. Oleh karena itu, pembaruan pendidikan terus dilakukan untuk meningkatkan kualitas pendidikan nasional. Berbagai upaya telah dilakukan seperti pembaruan kurikulum, peningkatan kualiatas guru, penyediaan kepustakaan dan laboratorium, penataan manajemen pendidikan serta penerapan produk teknologi.

Program studi Pendidikan Teknik Mesin UNS merupakan salah satu sarana pembelajaran yang bertujuan untuk menghasilkan tenaga pendidik/guru profesional di bidang teknik mesin. Kualitas pembelajaran yang dilaksanakan dosen sangat mempengaruhi terhadap capaian pembelajaran mahasiswanya. Pembelajaran yang masih bersifat konvensional, menggunakan metode ceramah masih terlihat di program studi ini. Keberadaan proses belajar yang demikian membuat mahasiswa tidak antusias dalam pembelajaran. Oleh karenanya diperlukan konsep yang mudah dipelajari memberikan motivasi mahasiswa agar belajar lebih aktif baik di dalam maupun di luar perkuliahan.
Ketepatan dalam penggunaan metode pengajaran yang dilakukan oleh dosen akan dapat membangkitkan aktivitas dan minat terhadap mata kuliah yang diberikan dan pencapaian hasil belajar. Metode mengajar yang baik adalah metode yang sesuai dengan materi yang akan disampaikan, kondisi siswa, sarana dan prasarana yang tersedia serta tujuan pengajarannya, serta media yang baik membuat siswa lebih tertarik dalam pembelajaran.

E-learning merupakan salah satu model pembelajaran yang mulai banyak digunakan di pendidikan tinggi pada saat ini. Model pembelajaran ini memanfaatkan teknologi informasi dalam membantu dosen-mahasiswa terutama pada pengelolaan kegiatan belajar mengajarnya. Karena penggunaan alat bantu berbasis online ini bersifat mandiri, maka diperlukan aplikasi agar penggunakan media ini bersifat dua arah, terjadi komunikasi antara dosen dengan mahasiswa. E-learning berbasis MOODLE adalah salah satu learning management system (LMS) yang dilengkapi dengan berbagai fitur komunikasi dua arah. LMS ini digunakan dalam website e-learning FKIP dengan url http:semar.fkip.uns.ac.id.

Oleh karenanya, agar komunikasi pembelajaran berbasis e-learning ini dapat berjalan dan ditintak lanjuti, perlu adanya penelitian ini. Penelitian ini menjelaskan efektifitas komunikasi pembelajaran online 
dalam mata kuliah body otomotif di PTM FKIP UNS.

\section{LANDASAN TEORI}

\section{Keefektifan komunikasi Pembelajaran}

Komunikasi adalah proses sistematik di mana individu-individu saling berinteraksi sampai menciptakan simbol-simbol dan menafsirkan makna. Salah satu area yang lebih mengasyikan dari bidang komunikasi modern adalah media dan teknologi baru (Wood, 2004).

Dalam kegiatan belajar mengajar, komunikasi antar pribadi merupakan suatu keharusan, agar terjadi hubungan yang harmonis antara pengajar dengan peserta belajar. Keefektifan komunikasi dalam kegiatan belajar mengajar ini sangat tergantung dari kedua belah pihak. Akan tetapi karena pengajar yang memegang kendali kelas, maka tanggung jawab terjadinya komunikasi dalam kelas yang sehat dan efektif terletak pada tangan pengajar. Keberhasilan pengajar dalam mengemban tanggung jawab tersebut dipengaruhi oleh keterampilannya dalam melakukan komunikasi ini.

Pembelajaran sebagai subset dari proses pendidikan harus mampu memberikan kontribusi terhadap peningkatan kualitas pendidikan, yang pada ujungnya akan berpengaruh terhadap peningkatan kualitas sumber daya manusia. Agar pembelajaran dapat mendukung peningkatan mutu pendidikan, maka dalam proses pembelajaran harus terjadi komunikasi yang efektif, yang mampu memberikan kefahaman mendalam kepada peserta didik atas pesan atau materi belajar.

Komunikasi efektif dalam pembelajaran merupakan proses transformasi pesan berupa ilmu pengetahuan dan teknologi dari pendidik kepada peserta didik, dimana peserta didik mampu memahami maksud pesan sesuai dengan tujuan yang telah ditentukan, sehingga menambah wawasan ilmu pengetahuan dan teknologi serta menimbulkan perubahan tingkah laku menjadi lebih baik. Pengajar adalah pihak yang paling bertanggungjawab terhadap berlangsungnya komunikasi yang efektif dalam pembelajaran, sehingga dosen sebagai pengajar dituntut memiliki kemampuan berkomunikasi yang baik agar menghasilkan proses pembelajaran yang efektif.

Keefektifan komunikasi (Bertrand, 1978) terhadap media meliputi lima komponen yaitu : daya tarik (attraction), pemahaman (comprehension), penerimaan (acceptability), keterlibatan (self-involvement) dan keyakinan (persuasion). Empat komponen pertama (daya tarik, pemahaman, penerimaan dan keterlibatan) relatif mudah untuk dilakukan pengukuran.

\section{E-learning}

E-Learning dapat didefinisikan sebagai sebuah bentuk teknologi informasi yang diterapkan di bidang pendidikan dalam bentuk sekolah maya. E-learning merupakan dasar dan konsekuensi logis dari perkembangan teknologi informasi dan komunikasi. Dengan e-learning, peserta didik tidak perlu duduk dengan manis di ruang kelas untuk menyimak setiap ucapan dari seorang guru secara langsung. E-learning juga dapat mempersingkat jadwal target waktu pembelajaran, dan tentu saja menghemat biaya yang harus dikeluarkan oleh sebuah program studi atau program pendidikan.

Dalam berbagai literatur, e-learning didefinisikan sebagai berikut: e-learning is a generic term for all technologically supported learning using an array of teaching and learning tools as phone bridging, audio and videotapes, teleconferencing, satellite transmissions, and the more recognized web-based training or computer aided instruction also commonly referred to as online courses (Soekartawi, Haryono dan Librero, 2002).

Dengan demikian maka e-learning adalah pembelajaran yang pelaksanaannya didukung oleh jasa teknologi seperti telepon, audio, vidiotape, transmisi satellite atau komputer.

\section{METODOLOGI PENELITIAN}

Penelitian ini adalah penelitian kualitatif. Metode yang digunakan adalah metode Ex Post Facto. Metode ini mengungkap hal-hal yang sudah ada tanpa memberi perlakuan pada subyek penelitian atau tidak memberikan perlakuan terhadap variabel yang diteliti, dan metode ini digunakan untuk mengungkap kembali keadaan atau kejadian yang berlanjut. Sebagaimana diungkapkan Sumadi Suryabrata (1997 : 27) bahwa:"Ex Post Facto artinya data dikumpulkan setelah kejadian yang berlangsung (lewat)."

Hal yang harus dilakukan dalam penelitian dengan metode Ex Post Facto ini adalah menegaskan suatu 
konsep atau memberikan gambaran yang tepat dari suatu gejala, sehingga harus dilakukan terus menerus atau seksama supaya kesimpulan yang diperoleh dapat benar-benar representatif.

Tempat penelitian di Program Studi Pendidikan Teknik Mesin dan Kejuruan JPTK FKIP UNS. Sedangkan waktu penelitian dilakasanakan mulai bulan September 2013 sampai dengan Desember 2013.

Instrumen yang digunakan dalam penelitian ini adalah angket atau kuesioner. Menurut Suharsimi Arikunto (1999 : 229) bahwa,"Angket atau kuesioner adalah sejumlah pertanyaan tertulis yang digunakan untuk memperoleh informasi dari responden dalam arti laporan tentang pribadinya atau hal-hal yang diketahui".

Kuesioner ini digunakan untuk mendapatkan data-data dari variabel bebas motivasi belajar dan data variabel terikat minat berwiraswasta. Kuesioner yang digunakan adalah jenis kuesioner tertutup. Menurut Suharsimi Arikunto (1999 : 200)," Kuesioner tertutup sudah disediakan jawabannya sehingga responden tinggal memilih". Angket ini ditujukan kepada mahasiswa sebagai populasi dan sampel penelitian.

Analisis data yang digunakan adalah analisis deskriptif kualitatif. Bulaeng (2004) menyatakan bahwa penelitian menentukan apakah data pengamatan sesuai atau tidak dengan pernyataan penelitian atau hipotesis, dan apakah peneliti merumuskan kerangka teoritis secara tepat. Analisis data ini akan membawa peneliti ke tahap konseptual penelitian, di mana proses penelitian dilanjutkan dengan merumuskan pernyataan masalah. Setelah kuisioner dikumpulkan dari mahasiswa, selanjutnya jawaban dilakukan proses koding. Data rasio, interval maupun ordinal dilakukan koding. Analisis data yaitu dengan :

a) Statistik deskriptif digunakan untuk melihat gambaran data responden berdasarkan efektivitas komunikasi pembelajaran.

b) Distribusi frekuensi digunakan untuk mengetahui penyebaran data yang dikelompokkan

\section{HASIL DAN PEMBAHASAN}

1. Gambaran Umum
Perkuliahan mata kuliah Body Otomotif merupakan salah satu mata kuliah pilihan bagi mahasiswa Pendidikan Teknik Mesin yang mengambil konsentrasi Mesin Otomotif. Mata kuliah ini mempunyai standar kompetensi agar mahasiswa mampu memperbaiki dan merawat Body Otomotif kendaraan.

Perkuliahan menggunakan sistem modul yang diupload di dalam sistem elearning FKIP UNS dengan alamat URL: http://semar.fkip.uns.ac.id. Berikut ini gambar dari halaman muka mata kuliah Body Otomotif di dalam sistem e-learning.

2. Efektifitas Komunikasi Pembelajaran

$$
\text { Komunikasi merupakan proses }
$$

sistematik di mana individu-individu saling berinteraksi sampai menciptakan simbol-simbol dan menafsirkan makna. Salah satu area yang lebih mengasyikan dari bidang komunikasi modern adalah media dan teknologi baru (Wood, 2004). Pembelajaran efektif ditunjukkan oleh ketepatan komponen-komponen yang digunakan untuk mencapai tujuan belajar itu sendiri. Killen (1988) mengungkapkan hakekatnya pembelajaran berkualitas dan efektif berkaitan pencapaian hasil belajar yang ditetapkan, melalui proses pembelajaran yang dirancang oleh pengembang program (Abdulhak \& Anwas, 2003). Komunikasi dinilai efektif apabila rangsangan yang disampaikan dan dimaksudkan oleh pengirim atau sumber, berkaitan erat dengan rangsangan yang ditangkap dan dipahami oleh penerima. Goyer (1970) dalam Tubbs (1996) mengatakan semakin besar kaitan antara yang dimaksud dengan respons yang diterima, semakin efektif pula komunikasi yang dilakukan. Efektivitas komunikasi pembelajaran Body Otomotif di elearning FKIP UNS dapat diketahui dengan mengukur tingkat pemahaman, penerimaan, peningkatan pengetahuan, sikap dan tindakan. Untuk mengetahui hasil pengukuran efektivitas komunikasi pembelajaran, bahwa skor responden ditunjukkan pada Tabel 1 dan sebaran responden ditunjukkan pada Tabel 2.

Tabel 1. Rataan Skor Responden Menurut Efektivitas Komunikasi Pembelajaran 


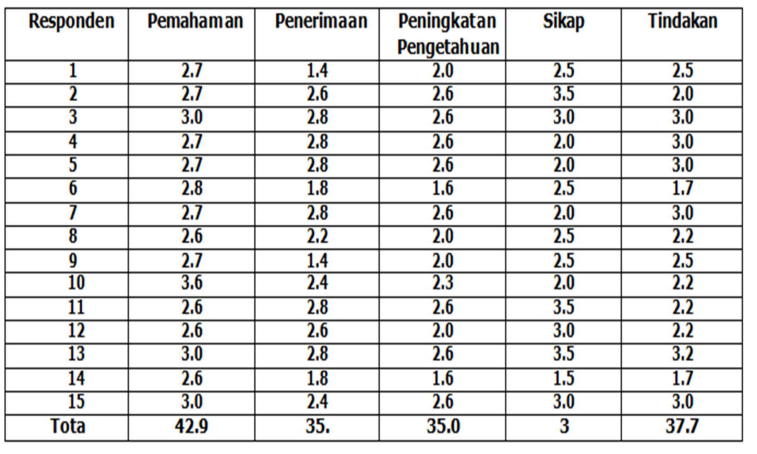

Tabel 2. Sebaran Responden Menurut Efektivitas Komunikasi Pembelajaran

\begin{tabular}{|c|c|c|c|c|c|}
\hline No. & $\begin{array}{l}\text { Efektifitas Komunikasi } \\
\text { Pembelajaran }\end{array}$ & Kategori & $\begin{array}{l}\text { Jumlah } \\
\text { Responden }\end{array}$ & $\begin{array}{l}\text { Persentase } \\
(\%)\end{array}$ & Rataan Skor \\
\hline \multirow[t]{4}{*}{1} & Pemahaman & Rendah & & & \\
\hline & & Sedang & 11 & 73 & \\
\hline & & Tinggi & 4 & 23 & \\
\hline & & Subtotal & 15 & 100 & 2.86 \\
\hline \multirow[t]{4}{*}{2} & Penerimaan & Rendah & 4 & 23 & \\
\hline & & Sedang & 11 & 73 & \\
\hline & & Tinggi & - & - & \\
\hline & & Subtotal & 15 & 100 & 2.36 \\
\hline \multirow[t]{4}{*}{3.} & Peningkatan & Rendah & 2 & 13 & \\
\hline & & Sedang & 13 & 87 & \\
\hline & & Tinggi & - & - & \\
\hline & & Subtotal & & 100 & 2.33 \\
\hline \multirow[t]{4}{*}{4.} & Sikap & Rendah & 1 & 7 & \\
\hline & & Sedang & 8 & 53 & \\
\hline & & Tinggi & 6 & 40 & \\
\hline & & Subtotal & 15 & 100 & 2.60 \\
\hline \multirow[t]{4}{*}{5.} & Tindakan & Rendah & 2 & 13 & \\
\hline & & Sedang & 7 & 47 & \\
\hline & & Tinggi & 6 & 40 & \\
\hline & & Subtotal & 15 & 100 & 2.52 \\
\hline \multicolumn{5}{|c|}{ Total } & 2.53 \\
\hline
\end{tabular}

Keterangan :

$1,0-1,9=$ Rendah

$2,0-2,9=$ Sedang

$3,0-4,0=$ Tinggi

\section{a. Pemahaman}

Pemahaman merupakan proses penterjemahan simbol-simbol pesan setiap modul ke dalam bentuk sinyal-sinyal yang disimpan dalam memory menjadi suatu makna yang dapat dipahami atau dimengerti. Proses penterjemahan menjadi suatu makna dengan cara mencocokkan sinyal-sinyal pengalaman yang telah terekam atau menyimpan sinyal-sinyal baru ke dalam memory. Pemahaman mahasiswa diharapkan sesuai dengan pesan yang dikirim sumber.

Data penelitian pemahaman menunjukkan bahwa (1) sebanyak 7 jawaban mahasiswa mengaku sulit

memahami, (2) sebanyak 36 jawaban mahasiswa mengaku sebagian kecil memahami, (3) sebanyak 61 jawaban mahasiswa mengaku cukup dapat memahami, (4) sebanyak 31 jawaban mahasiswa mengaku sebagian besar dapat memahami. Hasil penelitian mengenai pemahaman menunjukkan sebagian besar mahasiswa cukup dapat memahami materi modul. Hal ini ditunjukkan bahwa 11 mahasiswa (73\%) mempunyai tingkat pemahaman dalam kategori sedang dan 4 mahasiswa (23\%) mempunyai tingkat pemahaman dalam kategori tinggi. Hasil rataan skor diperoleh nilai sebesar 2.86 atau mendekati tinggi.

\section{b. Penerimaan}

Penerimaan berkaitan dengan persepsi mahasiswa terhadap media dalam pelaksanaan kursus secara online. Penerimaan ini menyangkut tingkat kejelasan penyampaian simbol pesan melalui tulisan, gambar-gambar, suara, dan keserasiannya (tulisan, gambar dan suara) sebagai media komunikasi. Sumber media komunikasi berbentuk berkas multimedia.

Data penelitian penerimaan menunjukkan (1) sebanyak 12 jawaban mahasiswa menyatakan tidak jelas, (2)

sebanyak 28 jawaban mahasiswa menyatakan cukup jelas, (3) sebanyak 31 jawaban mahasiswa menyatakan jelas, (4) sebanyak 4 jawaban mahasiswa menyatakan sangat jelas. Data lainnya adalah seorang mahasiswa menyatakan suara modul sering tidak jelas karena faktor pembicara. Mahasiswa memberikan pernyataan tidak jelas, umumnya berkaitan dengan kualitas suara yang diterima.

Hasil penelitian menunjukkan peserta mata kuliah chasis da body dapat menerima media komunikasi

kategori sedang dengan persentase $73 \%$ - Hasil rataan skor penerimaan diperoleh nilai sebesar 2,36, berarti mode e-learning bisa dipergunakan mahasiswa sebagai media komunikasi pembelajaran dengan cukup jelas.

\section{c. Peningkatan Pengetahuan}

Peningkatan pengetahuan merupakan pengakuan jumlah pengetahuan

yang dapat diserap mahasiswa. Jumlah peningkatan pengetahuan bagi setiap mahasiswa mempunyai nilai yang relatif karena setiap mahasiswa mempunyai ukuran sendirisendiri.

Data penelitian menunjukkan (1) sebanyak 6 jawaban mahasiswa mengaku sedikit meningkatkan pengetahuan, (2) sebanyak 21 jawaban mahasiswa mengaku cukup banyak meningkatkan pengetahuan, (3) sebanyak 15 jawaban mahasiswa mengaku banyak meningkatkan pengetahuan, (4) Sebanyak 3 jawaban mahasiswa mengaku sangat banyak meningkatkan pengetahuan. Data lainnya adalah sebanyak 13 mahasiswa (87\%) 
jawabannya trmasuk kategori sedang. Dengan demikian hasil peningkatan pengetahuan yang diperoleh cukup.

Hasil keseluruhan rataan skor peningkatan pengetahuan diperoleh nilai sebesar 2.33 atau kategori sedang . Ini berarti e-learning dapat memberikan tambahan pengetahuan atau pengalaman dalam rekaman memory mahasiswa dengan jumlah relatif cukup.

Peningkatan pengetahuan berkaitan dengan peran beberapa faktor antara lain :

1) Kemauan belajar. Mahasiswa mempunyai motivasi belajar tinggi yang dapat menyebabkan munculnya kemauan belajar. Kemauan belajar dapat memberikan manfaat dalam menyerap materi pesan modul yang disampaikan oleh sumber. Dengan adanya kemauan belajar yang tinggi, mahasiswa mungkin bisa menyerap simbol pesan modul menjadi suatu makna sesuai pengiriman sumber dalam jumlah yang relatif banyak.

2) Ketekunan belajar. Mahasiswa mempelajari suatu pengetahuan dengan tekun dan sabar, memungkinkan mahasiswa bisa menyerap simbol pesan menjadi suatu makna sesuai pengiriman sumber dalam jumlah relatif banyak. Ketekunan merupakan suatu bentuk langkah mahasiswa untuk mempelajari sesuatu pengetahuan agar pesan modul dapat terekam dalam memory untuk jangka waktu cukup lama.

\section{d. Sikap}

Sikap ini relatif menetap pada diri mahasiswa, terutama dalam hal memberikan pendapat atau pendiriannya tentang isi pesan yang disampaikan oleh sumber. Setelah mahasiswa mempelajari materi dari berbagai sumber yang menyangkut kesamaan materi setiap modul, maka mahasiswa akan mempunyai sikap yang menjadi pilihannya.

Data penelitian mengenai sikap terhadap isi pesan sebagian topik modul yang disampaikan oleh sumber menunjukkan (1) enam jawaban mahasiswa menyatakan sebagian kecil setuju, (2) sebanyak 7 jawaban mahasiswa menyatakan cukup setuju, (3) sebanyak 10 jawaban mahasiswa menyatakan sebagian besar setuju, (4) sebanyak 7 jawaban mahasiswa menyatakan sikap sangat setuju.

Hasil penelitian mengenai sikap menunjukkan (1) sebanyak satu mahasiswa(7\%) memberikan sikap dengan kategori rendah, (2) sebanyak 8 mahasiswa (53\%) memberikan sikap dengan kategori sedang dan (3) sebanyak 6 mahasiswa (40\%) memberikan sikap dengan kategoritinggi. Oleh karena mahasiswa mendapatkan tugas membaca website lain, sehingga mahasiswa juga memperoleh informasi-informasi yang lebih luas. Atas dasar informasi-informasi tersebut mahasiswa dapat lebih mantap memberikan sikapnya terhadap isi pesan modul dalam pembelajaran. Dengan demikian mahasiswa dapat menerima informasi yang disampaikan sumber dan tidak memberikan bantahan atau perbandingan atas pendapat fihak lain yang bertentangan. Hasil rataaan skor sikap diperoleh nilai sebesar 2.60 atau sedang, berarti modul e-learning cukup untuk mengarahkan sikap mahasiswa terhadap isi pesan modul.

Menurut Hardjito (2004) ada empat faktor yang menentukan pembentukan sikap mahasiswa yaitu :

1) Keinginan. Sikap menentukan sesuatu yang disukai, diharapkan, diinginkan, dan mengesampingkan apa yang tidak diinginkan.

2) Informasi. Sikap timbul dari pengalaman yang merupakan hasil belajar atau informasi yang diterimanya.

3) Hubungan dengan kelompok. Sikap yang cenderung pada titik positif akan melahirkan respos positif, sebaliknya sikap yang cenderung pada titik negatif akan melahirkan respons negatif.

4) Kepribadian seseorang. Suatu sifat melekat pada diri seseorang dapat membentuk sikap. Misalnya sifat seseorang mudah menerima masukan dari teman sehingga masukan tersebut dapat mempengaruhi sikap.

\section{e. Tindakan}

Tindakan merupakan tingkah laku mahasiswa menyangkut hal-hal yang berkaitan dengan

menyelesaikan tugas, menambah pengetahuan berkat informasi yang dimiliki mahasiswa lain serta diseminasi pengetahuan yang telah diperoleh. Jadi tindakan ini pada prinsipnya adalah penambahan pengetahuan dan niat bertindak mahasiswa.

Data penelitian menunjukkan (1) sebanyak 3 mahasiswa tidak dapat menyelesaikan tugasnya, (2) sebanyak 20 mahasiswa menyelesaikan tugas melewati jangka waktu lebih dari dua hari, (2) sebanyak 2 mahasiswa menyelesaikan tugas 
antara satu hari hingga dua hari, (3) tidak ada mahasiswa yang dapat menyelesaikan tugas dalam waktu kurang dari satu hari.

Apabila mahasiswa lain mempunyai berkas (file) yang berkaitan dengan body otomotif, Separuh lebih mahasiswa (8 mahasiswa) menyatakan akan tetap melakukan akses internet. Tindakan tersebut mempermudah akses alamat wesite (internet) karena berkas biasanya terdapat alamat website. Sedangkan tindakan copy file karena berkas bisa dibaca secara elektronik dengan komputer miliknya.

Setelah mahasiswa memperoleh pengetahuan dari perkuliahan, data penelitian menunjukkan (1) sebanyak 10 mahasiswa akan mendiseminasikan sebagian kecil pengetahuan kepada teman lain atau adik kelas, (3) sebanyak 5 mahasiswa akan mendiseminasikan sebagian besar pengetahuan kepada teman lain atau adik kelas.

Hasil penelitian mengenai tindakan menunjukkan $13 \%$ mahasiswa kategori rendah dalam tindakan, $47 \%$ mahasiswa kategori sedang dalam tindakan dan 40\% mahasiswa kategori tinggi dalam tindakan. Sedangkan hasil rataan skor diperoleh nilai tindakan sebesar 2.52 atau sedang, berarti mode e-learning cukup mendorong mahasiswa untuk melakukan tindakan. Tindakan ini berkaitan dengan peran dari beberapa faktor, antara lain :

1) Kedisiplinan. Mahasiswa mampu mengatur waktu dalam menyelesaikan tugas yang diterimanya dengan baik atau tepat waktu. Keteraturan waktu ini dapat diperlihara mahasiswa karena mereka selalu disiplin.

2) Agresivitas. Faktor ini merupakan sifat mahasiswa dalam menghadapi sesuatu untuk melakukan tindakan. Seperti mahasiswa melakukan tindakan akses internet atau kopi berkas elektronik atau kopi print out. Tindakan merupakan kecepatan respon mahasiswa atas informasi yang dimiliki temannya.

3) Dermawan. Faktor ini merupakan sifat mahasiswa dalam melakukan diseminasi pengetahuan yang telah dimilikinya. Sifat ini melekat pada diri mahasiswa.
Mahasiswa mempunyai sifat berbeda-beda dalam kekikiran atau kepelitan sharing informasi kepada mahasiswa yang lain atau adik kelasnya.

Hasil rataan skor efektivitas komunikasi pembelajaran diperoleh nilai sebesar 2.53 atau sedang, berarti mode elearning cukup efektif untuk dipergunakan dalam komunikasi pembelajaran mahasiswa. Efektivitas komunikasi pembelajaran tersebut berkaitan secara langsung dengan aktivitas mode e-learning dan berkaitan secara tidak langsung dengan faktor personal, faktor lingkungan, dan media lain.

\section{KESIMPULAN DAN SARAN}

1. Simpulan

Penyampaian materi modul Body Otomotif melalui mode e-learning kepada mahasiswa Prodi PTM JPTK FKIP UNS dalam komunikasi pembelajaran dinilai cukup efektif. Hal ini dibuktikan bahwa (1) materi modul tersebut cukup dapat dipahami mahasiswa, (2) materi tulisan, gambar, suara, maupun keserasian ketiganya dalam modul dapat diterima mahasiswa dengan cukup jelas, (3) materi modul banyak cukup menambah pengetahuan mahasiswa, (4) mode e-learning mengarahkan sikap mahasiswa dengan sebagian setuju terhadap materi modul, (5) mode e-learning mendorong tindakan mahasiswa untuk menyelesaikan tugas dari modul e-learning, melakukan akses internet dan mengkopi berkas atau memfotokopi print out tentang informasi Body Otomotif yang dimiliki temannya, serta menyebarkan sebagian besar pengetahuan yang telah diperoleh dari modul distance learning.

\section{Saran}

Berdasarkan simpulan yang diperoleh dari kajian efektivitas komunikasi pembelajaran tersebut, maka saran yang dapat diberikan adalah : lebih mendorong kepada dosen dan mahasiswa agar senantiasa menggunakan ICT terutama e-learning sebagai media PBM agar berjalan efektif. 


\section{DAFTAR PUSTAKA}

Bertrand JT. (1978). Communications Pretesting. Chicago : Community and Family Study Center, University of Chicago.

Bulaeng A. (2004). Metode Penelitian Komunikasi Kontemporer. Yogyakarta : Andi.

Pembelajaran elektronik. (2013). Diperoleh 13 April 2013, dari http://id.wikipedia.org/wiki/Pembelajaran_elektronik

Pengertian e-learning. (2012). Diperoleh 10 Mei 2013, dari http://www.medukasi.web.id/2012/11/pengertian-e-learning.html

Soekartawi (2002), e-learning: Konsep dan Aplikasinya. Bahan-Ceramah/Makalah disampaikan pada Seminar yang diselenggarakan oleh Balitbang Depdiknas, Jakarta, 18 Desember 2002.

Subagyo. (2007). Efektifitas Komunikasi Pembelajaran dengan mode Distance Learning Berbasis Website. Bogor

Wood JT. (2004). Communcation Theories in Action : An Introduction. Australia : Wadsworth. 